\title{
Effects of the SW Atlantic burrowing crab Chasmagnathus granulata on a Spartina salt marsh
}

\author{
Alejandro Bortolus ${ }^{1, *}$, Oscar Iribarne ${ }^{2}$ \\ ${ }^{1}$ Becario CIC and ${ }^{2}$ Investigador CONICET, Biologia (FCEyN), Universidad Nacional de Mar del Plata, \\ CC 573 Correo Central (7600) Mar del Plata, Argentina
}

\begin{abstract}
In this work we evaluated the effect of the burrowing crab Chasmagnathus granulata on the soil quality and on the cordgrass Spartina densiflora in a SW Atlantic coastal lagoon (Argentina, $37^{\circ} 32^{\prime} \mathrm{S}, 57^{\circ} 19^{\prime} \mathrm{W}$ ). Soil hardness and percolation rates were higher outside the crab inhabited area than inside, and soil profiles showed 2 different strata in areas without crabs. Crabs were associated with low soil water content, a higher variability in $\mathrm{pH}$, and a homogeneous distribution of organic matter. Meiofaunal abundance was lower inside the area inhabited by crabs than outside. The water content of aboveground structures of $S$. densiflora was lower inside the crab populated areas. Leaf survival was lower inside the area inhabited by crabs than outside. In areas with new shoots (after burning by a brush fire) crabs depleted the aboveground plant structures. A caging experiment showed that crabs decreased leaf survival by herbivory. During the experiment, substrata was covered by sediment displaced by crabs, and the area showed less soil hardness and lower percolation rates than controls. Crabs decreased water content and organic matter on upper sediment layers. Meiofaunal abundance (arachnids and insects) was higher in control plots (without crabs) than in treatment plots. A field selection experiment showed that crabs decreased survival of young stems, but did not affect old stems. All this evidence suggests that $C$. granulata affects cordgrass production by herbivory on new shoots, and can change the physical characteristics of the environment, which may also indirectly affect $S$. densiflora production. Thus, the general belief that in Spartina marshes only a small proportion of primary production is consumed in situ may not apply to SW Atlantic Spartina marshes inhabited by crabs.
\end{abstract}

KEY WORDS: Spartina C Crabs · Marsh · Herbivory · Bioturbation · Fire

\section{INTRODUCTION}

The productivity of salt marshes is often higher than the productivity of most other ecosystems, and is considered the basis for estuarine food chains (Day et al. 1989). Several plant species of the genus Spartina are the dominant organisms in these ecosystems, and their performance and shoot-density appear to be related to edaphic factors arising from the drainage pattern, nutrient availability (principally $\mathrm{N}$ ), and oxygen concentrations (Mendelssohn et al. 1982). In certain cases, herbivory (mainly insects or domestic animals) is responsible for diminishing the productivity of these halophytes (Adam 1993). However, in salt marshes herbivores do not usually deplete vegetation, as they

•E-mail: bortolus@mdp.edu.ar are limited by the quality of their food plants (Valiela 1984), and only affect a small proportion of the primary production (Adam 1993). Halophytes protect themselves by means of spines, hairs, and chemical defenses when ripe (Valiela 1984), but these strategies are uncommon in shoots which are nitrogen-rich, low in fiber, and consist of more digestible tissues (Howe \& Westley 1988, Wolcott \& O'Connor 1992). Thus, if the low impact of herbivores in marsh areas is due to the low content in nutrients or defenses of these plants (Valiela 1984, Day et al. 1989), their effect in areas with a high proportion of new shoots may be greater than expected for mature areas.

One of the factors that can largely affect the proportion of new shoots is brush fire. Fire is one of the few perturbations that can regularly kill mature plants, and is an important agent in structuring communities 
(Bond \& van Wilgen 1996). Recovery of systems that have been affected by fire can proceed very differently, depending on the effect of factors that act before and after the fire has occurred (Bond \& van Wilgen 1996). In salt marshes of the SW Atlantic, fire is increasingly being used as a tool to renew food for cattle grazing, to avoid accidental fire, and to control plagues (e.g. rodents, insects). Given that, generally, streamside areas are used as natural limits for the extension of the areas to be burned, large grassland areas inhabited by the SW Atlantic burrowing crab Chasmagnathus granulata are usually also affected.

Chasmagnathus granulata is one of the most abundant macroinvertebrates (up to $40 \mathrm{~mm}$ carapace width Boschi 1964) in salt marshes of the SW Atlantic (southern Brazil to northern Patagonia, Argentina; Boschi 1964, Cabrera 1978, Iribarne et al. 1997). It is distributed in almost all the zones of the marsh intertidal; in the soft bare sediment flats and in areas with Spartina densiflora (Boschi 1964, Iribarne et al. 1997). C. granulata is extremely well adapted to exposure to atmospheric air, showing larger gill areas than other semiterrestrial crab species (Santos et al. 1987). This characteristic allows the crabs to occupy the uppermost part of the intertidal, and they are frequently observed living at great distances (several hundred meters) from the water's edge in the marsh areas (Spivak et al. 1994). As suggested for Uca crabs (e.g. Teal \& Kanwisher 1961, Bertness 1985), their burrowing activity could oxygenate marsh soil, enhance soil drainage, and modify sediment meiofaunal abundance. Their burrows can extend up to $1 \mathrm{~m}$ into the marsh sediment and density can be as high as 70 crabs $\mathrm{m}^{-2}$ removing between $2.5 \mathrm{~kg} \mathrm{~m}^{-2}$ (in the marsh) and $6 \mathrm{~kg} \mathrm{~m}^{-2}$ (in the mud flat) of sediment per day (Iribarne et al. 1997). The burrow shape differs between areas; straight, long and vertical tunnels are found in the vegetated area, while burrows have a lower angle and are shorter with a much larger (and funnel shaped) entrance in mud flats. Stomach contents also differ between habitats. Pieces of plants dominated the contents in the Spartina-dominated area, while sediment (with polychaetes, diatoms, ostracods, and nematodes) dominated in the mud flats, which indicates that crabs are mainly deposit feeders in mud flats and herbivores in the Spartina-dominated areas (Iribarne et al. 1997). The plant species dominant in areas populated by crabs is the cordgrass $S$. densiflora (Olivier et al. 1972, Cabrera 1978), a halophyte with short rhizomes and a 1 to $1.5 \mathrm{~m}$ high stem, often living in salty marsh areas of southern South America (Cabrera 1978). Given that Spartina spp. are probably the most important source of primary production in most marshes (Mitsch \& Gosselink 1993), the high density of crabs, and the important role that deposit feeding has on sediment compo- sition (e.g. Rhodes 1967), this burrowing crab is likely to be a critical species in marsh production and marsh integrity. Despite these facts, little attention has been paid to the impact of their burrowing and deposit feeding activities on SW Atlantic salt marsh communities and sediment dynamics.

The purpose of this work was to evaluate by sampling and experiment the effects of Chasmagnathus granulata on soil characteristics and on the cordgrass Spartina densiflora, both in mature grasslands of a SW Atlantic coastal lagoon and in areas of rejuvenation. after a rapid brush fire. In particular, we evaluated the relationships between the abundance of crabs and (1) sediment permeability and hardness, $\mathrm{pH}$ profiles, water content, soil structure, and meiofaunal abundance; and (2) area covered by $S$. densiflora, their aboveground and belowground biomass, stem density, and water content of the aboveground plant structures. Field experiments were also performed to evaluate patterns previously found.

\section{MATERIAL AND METHODS}

Study area. The study was performed in the Mar Chiquita coastal lagoon (Argentina, $37^{\circ} 32^{\prime}$ to $37^{\circ} 45^{\prime} \mathrm{S}$, and $57^{\circ} 19^{\prime}$ to $57^{\circ} 26^{\prime} \mathrm{W}$ ), a body of brackish water $\left(46 \mathrm{~km}^{2}\right)$ affected by low amplitude tides $(\leq 1 \mathrm{~m}$; Spivak et al. 1994) and characterized by mudflats and a large surrounding Spartina densiflora area (Olivier et al. 1972, Cabrera 1978, Fasano et al. 1982). The streamside of these cordgrass areas is mostly inhabited by the burrowing crab Chasmagnathus granulata (Cabrera 1978, Spivak et al. 1994, Iribarne et al. 1997). To investigate the relationships between marsh vegetation and the presence of crabs we chose 2 types of marsh areas: a mature one and one that was regrowing after a brush fire. In both environments $S$. densiflora was the dominant species, and in both there were areas populated by crabs and nearby areas free of them.

Relationship between crabs, soil structure and meiofauna. To evaluate the relationship between the presence of crabs and the soil quality, we performed the following observations of physical and chemical soil characteristics, inside a cordgrass area populated by crabs and in a nearby (distance approximately $10 \mathrm{~m}$ ) cordgrass area without crabs.

Percolation rates were measured in both areas with an open-ended, calibrated plastic cylinder $(4.5 \mathrm{~cm}$ diameter, $500 \mathrm{ml}$ volume) that was inserted $2 \mathrm{~cm}$ into the sediment and filled with estuarine water. The volume of water draining into the substrate per unit of time was then recorded during a 5 min period $(21$ replicates site ${ }^{-1}$ ). Penetrability was measured (with 20 replicates site $^{-1}$ ) as the pressure (expressed in Newtons 
$\mathrm{cm}^{-2}$ ) necessary for compressing the spring of a piston (diameter: $2 \mathrm{~cm}$ ) that was forced into the sediment to a standard depth (following Brown \& McLachlan 1990). Since this value decreases with the increasing penetrability of the sediment, low numbers indicate soft sediments, whereas high numbers indicate harder sediments.

$\mathrm{pH}$ is an almost constant parameter of the marsh soil, which can affect plant production (Day et al. 1989). $\mathrm{pH}$ measurements were obtained from the surface sediment, and at 20,40,60, and $80 \mathrm{~cm}$ depth (sample volume: $393 \mathrm{~cm}^{3}$ ). These profiles were obtained from a cordgrass marsh with crabs and from a closed cordgrass marsh without crabs. The $80 \mathrm{~cm}$ depth limit was determined by the presence of the water table, which is the maximum depth reached by crabs (Iribarne et al. 1997). The null hypothesis of no relationship between depth and the $\mathrm{pH}$ of sediment samples was evaluated by a correlation analysis (Zar 1984) for areas with and without crabs. A similar sampling procedure was also used to evaluate soil water content. Water content was determined on the basis of the difference between initial weight and final weight of samples that were oven dried at $75^{\circ} \mathrm{C}$ until reaching constant weight. Ash-free dry weights (AFDW) were then obtained from the same samples combusted at $500^{\circ} \mathrm{C}$ for $24 \mathrm{~h}$.

Random soil samples ( $\mathrm{n}=63,10 \mathrm{~cm}$ diameter, sample volume: $393 \mathrm{~cm}^{3}$ ) were taken in monospecific Spartina densiflora zones within the study area. Before that, crab burrows per square meter (a good estimator of crab abundance; authors' pers. obs.) were also counted in each place where soil was sampled (sample area: $0.5 \times 0.5 \mathrm{~m})$. To estimate the volume $\left(\mathrm{l} \mathrm{m}^{-2}\right)$ of substrate excavated from crab burrows, the burrows from 10 randomly chosen $0.5 \times 0.5 \mathrm{~m}$ areas in the study area were filled with a known volume of fine-grain dry sand. In the same areas we counted the number of burrows, as an estimate of the number of crabs. To evaluate if crabs affect color, texture, and structure of soil, we compared soil profiles ( $40 \mathrm{~cm}$ deep) from the cordgrass marsh area with crabs and from a nearby cordgrass marsh without crabs. A visual description in terms of shape and appearance of the soil surface was also recorded (following Strahler \& Strahler 1994). Colors of the soil layers were classified using the Munsell soil color chart (Munsell 1975).

We sampled meiofaunal organisms from inside the cordgrass area populated by crabs and from a neighboring cordgrass area without crabs. Ten samples were collected from the soil surface to $5 \mathrm{~cm}$ depth with a corer $\left(15 \mathrm{~cm}\right.$ diameter, sample volume: $\left.-884 \mathrm{~cm}^{3}\right)$, and meiofaunal organisms were obtained using the Berlese funnel technique (Southwood 1975). Although this technique was originally designed for terrestrial soil (focusing on insect populations), it worked effec- tively in salt marsh sediments (A. Bortolus pers. obs.). All organisms collected were identified and counted.

Relationship between crabs and characteristics of a mature marsh vegetation. The relationship between the density of crabs and the substrata covered by Spartina densiflora (as a vertical projection of the canopy), and stem density of $S$. densiflora were evaluated by choosing 62 random sites ( $1 \mathrm{~m}^{2}$ each) in monospecific $S$. densiflora zones within the study area. Within each site we estimated crab density, percentage of substrata covered by $S$. densiflora, and its stem density. From inside and outside the marsh area populated by crabs we randomly selected ten $1 \mathrm{~m}^{2}$ plots per area, where the aboveground parts of $S$. densiflora lleaves and stems) were clipped at ground level and oven dried at $75^{\circ} \mathrm{C}$ until reaching constant weight. Water content of aboveground structures of $S$. densiflora was estimated as the difference between wet weight and dry weight. Then, five $0.30 \mathrm{~m}$ diameter cores $(0.20 \mathrm{~m}$ depth) were collected per area; the belowground parts of $S$. densiflora (rhizomes and roots) were separated by hand and then oven dried (at $75^{\circ} \mathrm{C}$ until reaching constant weight) and weighed.

Relationship between crabs and characteristics of a recently burned marsh. This area had been affected by a fast-moving fire (surface fire) which permits the recovery of plants (Barbour et al. 1987). However, to test this assumption we unearthed several plants and observed if belowground tissues were burned or damaged after the fire. To compare changes in biomass of Spartina densiflora $20 \mathrm{~d}$ after the burning, two $0.30 \mathrm{~m}$ diameter cores $(0.20 \mathrm{~m}$ depth) were collected from areas with and without crabs. From these samples the aboveground (leaves and stems) and belowground (rhizomes and roots) parts of $S$. densiflora were separated, oven dried (at $75^{\circ} \mathrm{C}$ until reaching constant weight), and then weighed.

To evaluate growth rate and survival of leaves of Spartina densiflora, we observed 60 leaves $(3$ to $3.5 \mathrm{~cm}$ length) for $7 \mathrm{~d}$ (15 to 22 March 1996), which had been randomly chosen and located in a line parallel to the tidal line. Half of them were in areas with crabs and half in areas without crabs. During this period we obtained daily measurements of growth and survival of these leaves. To estimate growth rate, permanent marks were put on the leaf base and $3 \mathrm{~cm}$ from the base. Growth of each leaf was estimated by measuring the distance between the 2 marks every $24 \mathrm{~h}$. Leaf survival was quantified by calculating the percentage of daily survival during the study. On a daily basis, the initial number of leaves was maintained constant by incorporating new leaves in observations as needed to compensate for mortality.

Experimental evaluation of the effect of crabs on cordgrass and soil structure. A manipulative experi- 
ment was designed to examine the hypothesis that crabs can affect the growth of Spartina densiflora, soil quality, and associated meiofauna. The experiment was deployed in a marsh area recently affected by fire (20 d after fire), vegetated by $S$. densiflora, and not inhabited by crabs, but located $3 \mathrm{~m}$ from the area inhabited by crabs. It consisted of (1) treatment plots: $1 \times 1 \mathrm{~m}$ cages ( $2 \mathrm{~cm}$ mesh size, $40 \mathrm{~cm}$ high) that were placed to include crabs. In these cages, artificial burrows (13 burrows $\mathrm{m}^{-2}$ ) extending down to the water table were constructed homogeneously within each cage. Then we added 1 crab per burrow, and the experiment was periodically observed to be sure that crabs were still alive and active. Given that the experiment was performed with medium size crabs (carapace width $\geq 2.5 \mathrm{~cm}$ ) to keep crabs within the cages, the experimental density was lower than field density. Experiments also included (2) control plots: $1 \times 1 \mathrm{~m}$ areas without disturbance were demarcated between treatment plots as controls.

Treatment plots were randomly distributed along a line parallel to the tidal level, and each treatment was replicated 5 times. For this experiment we performed 2 measurements that accounted for different degrees of crab activity. The first measurement was on 3 April 1996 (end of summer), when crabs were still active, and the second measurement was obtained on 15 October 1996 (end of winter), after the low crab activity period. Each time, we counted the number of leaves of Spartina densiflora exhibiting signs of herbivory in each plot. To avoid border effects counts were taken in the central area $(0.6 \times 0.6 \mathrm{~m}$ area $)$ of each replicate. On 15 October 1996 we also measured percolation rate and soil hardness in both treatment (outside the burrows) and control plots.

To evaluate if crabs affect color, texture, and structure, we compared soil profiles (as previously described) from treatment and control plots. The sample was obtained on 10 November 1997 (end of spring), when crabs returned to their maximum activity. A visual description in terms of shape and appearance of the soil surface was also recorded (following Strahler \& Strahler 1994). Colors of the soil layers were classified using the Munsell soil color chart (Munsell 1975). pH measurements were obtained from the surface sediment, and at 20,40,60, and $80 \mathrm{~cm}$ depth (sample volume: $393 \mathrm{~cm}^{3}$ ). These profiles were obtained from treatment and control plots.

We designed a $24 \mathrm{~h}$ field selection experiment which consisted of 10 randomly chosen $0.5 \times 0.5 \mathrm{~m}$ areas that were cleaned by clipping the aboveground plant structures at ground level. Within these cleaned areas 10 young stems (approximately $0.1 \mathrm{~m}$ total length, and totally green) were interspersed (distance between stems was $0.1 \mathrm{~m}$ ) with 10 mature stems $(0.5$ to $1 \mathrm{~m}$ total length). All these stems were obtained from the surrounded marsh by clipping them at ground level, discarding stems with signs of damage.

Data analysis. The null hypothesis of no differences in individual variables between areas with and without crabs was evaluated with a Welch-approximation $t$-test $\left(t_{c} ; \operatorname{Zar} 1984\right)$. When variances were not found homogeneous ( $F$-test), the differences in mean values were evaluated with a nonparametric $U$-test ( $\operatorname{Zar} 1984$ ). The relationships between each variable and soil depth were evaluated by a correlation analysis (Zar 1984). ANOVA was performed only when the analyzed variable was found to be independent of depth (i.e. no correlation). The relationships between crab density and area covered by plants and density of stems of Spartina densiflora were also evaluated independently with a correlation analysis. The null hypotheses of no effects of the presence of crabs on the mean growth rate or on leaf survival of $S$. densiflora were separately evaluated using a paired $t$-test ( $\operatorname{Zar} 1984$ ), where each pair was the average of data obtained for each area during the same day.

\section{RESULTS}

\section{Relationship between crabs, soil structure and meiofauna}

The soil percolation rate was significantly higher in the area not populated by crabs $\left(\bar{x}=8.91 \mathrm{ml} \mathrm{min}^{-1}\right.$, $\mathrm{SD}=9.59, \mathrm{n}=21)$ than in the area with crabs $(\bar{x}=$ $0.38 \mathrm{ml} \mathrm{min}^{-1}, \mathrm{SD}=0.52, \mathrm{n}=21 ; \mathrm{t}_{\mathrm{c}}=12.3, \mathrm{df}=22, \mathrm{p}<$ $0.05)$. Soil hardness was also significantly higher outside the crab populated area $\left(\bar{x}=90.03 \mathrm{~N} \mathrm{~cm}^{-2}, \mathrm{SD}=\right.$ 16.24, $\mathrm{n}=20)$ than inside $\left(\bar{x}=65.13 \mathrm{~N} \mathrm{~cm}^{-2}, \mathrm{SD}=14.49\right.$, $\left.\mathrm{n}=20 ; t_{\mathrm{c}}=5.1, \mathrm{df}=37, \mathrm{p}<0.05\right)$.

There was no correlation between $\mathrm{pH}$ and depth at any site (with crabs: $r^{2}=0.009, n=15, p>0.05$; without crabs: $r^{2}=0, n=15, p>0.05$; Fig. 1). Relative water content of the sediment showed an increasing trend in the area with crabs from $12 \%$ to $25 \%\left(\mathrm{r}^{2}=0.9, \mathrm{n}=15\right.$, $\mathrm{p}<0.05$; Fig. 1). In the area without crabs higher water contents were found at the surface $(26.5 \%)$ and at the greatest depth (24\%); minimum values appeared at intermediate depths (17.6\%; Fig. 1). However, there was no correlation with depth $\left(\mathrm{r}^{2}=0.03\right.$, df $=15, \mathrm{p}>$ 0.05 ; ANOVA: $F=3.6, \mathrm{df}=10, \mathrm{p}>0.05$ ). Water content of the sediment was significantly higher in areas without than in those with crabs at 0 and $20 \mathrm{~cm}$ depths but not in deeper layers (Fig. 1). The crab density showed a negative correlation with the soil water content of the upper soil level $\left(r^{2}=0.30, n=54, p<0.05\right.$; Fig. 2B). Within areas without crabs AFDW showed a negative correlation with depth $\left(\mathrm{r}^{2}=0.5, \mathrm{n}=15, \mathrm{p}<0.05\right)$ but not 

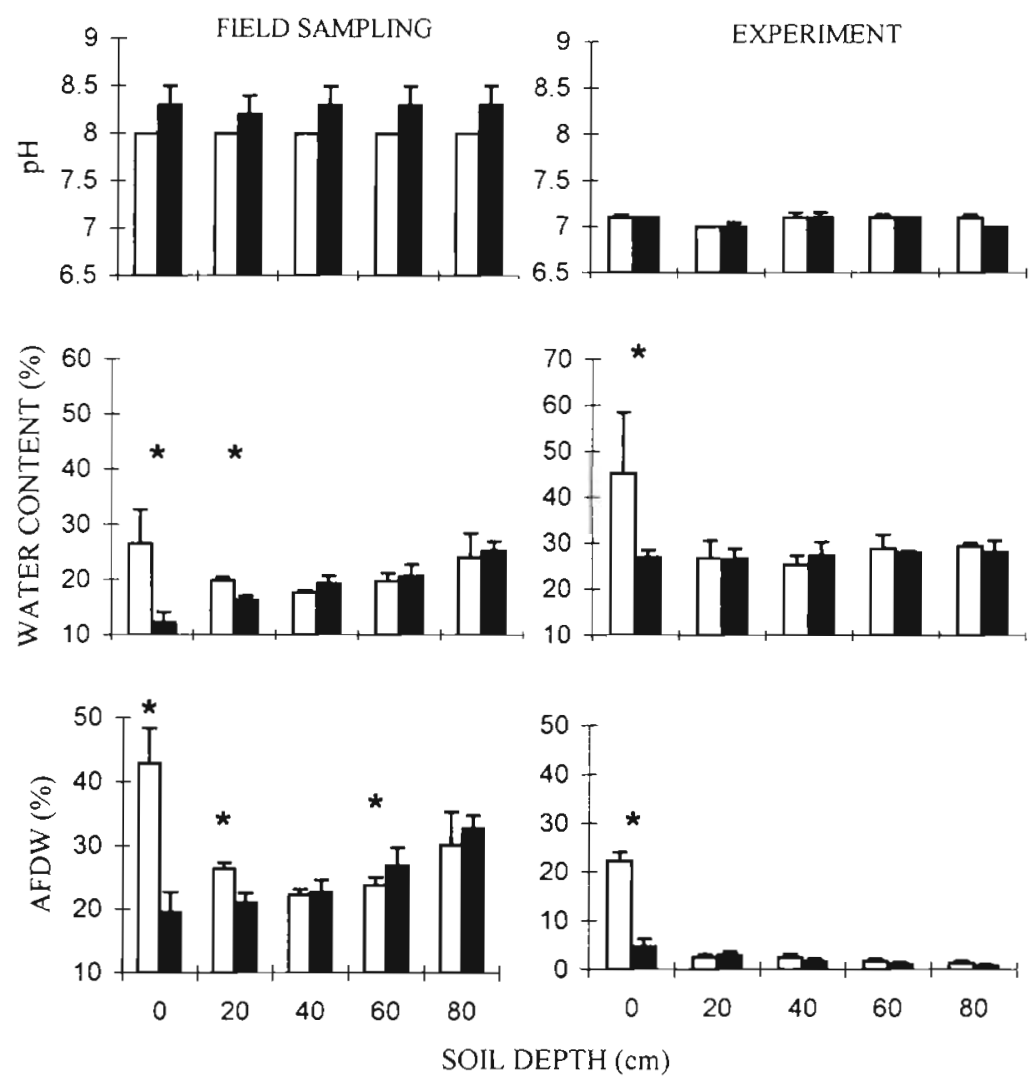

Fig. 1. Soil $\mathrm{pH}$, relative water content, and ash free dry weight (AFDW) at $0,20,40,60$ and $80 \mathrm{~cm}$ depth within cordgrass areas inhabited (black bars) and not inhabited (open bars) by the burrowing crab Chasmagnathus granulata. Values are expressed as $\bar{x}+\mathrm{SD}$. Asterisks indicate significant $t_{\mathrm{c}}$-test values $(\mathrm{df}=4, \mathrm{p}<0.05)$

in areas with crabs $\left(\mathrm{r}^{2}=0.001, \mathrm{n}=54, \mathrm{p}>0.05\right.$; Fig. 1$)$. Areas without crabs showed significantly higher values of AFDW in the 2 surface layers $(0,20 \mathrm{~cm}$ depth), and at $60 \mathrm{~cm}$ depth higher values were found in areas with crabs (Fig. 1).

The mean crab density in the study area was 60 ind. $\mathrm{m}^{-2}\left(\mathrm{SD}=17.7, \mathrm{n}=30 ; \mathrm{max}=96\right.$ ind. $\left.\mathrm{m}^{-2}\right)$, and the burrows represented an empty space of $10.91 \mathrm{~m}^{-2}(\mathrm{SD}=$ $2.9, \mathrm{n}=10$ ). The soil profile shows 2 clear strata in the area not populated by crabs, but only one homogeneous layer when crabs were present (Table 1). The upper stratum in the area not populated by crabs is well-developed topsoil, while there is a large degree of mixing in areas where crabs are abundant. The texture and consistency were similar between areas. The meiofaunal organisms collected from inside cordgrass areas populated and non-populated by crabs were mites (oribatids, prostigmatids, astigmatids, and mesostigmatids), spiders, and a few larval and adult insects (Collembola, Diptera and Coleopteran). The sampling at the beginning of the experiment showed that total abundance of meiofaunal organisms (arachnids + insects + larvae) was higher in areas not populated by crabs $\left(\bar{x}=480.8\right.$ ind $\mathrm{m}^{-2}, \mathrm{SD}=$ $238.8, \mathrm{n}=10$ ) than in areas populated by crabs $\left(\bar{x}=107.5\right.$ ind. $\mathrm{m}^{-2}, \mathrm{SD}=72.8, \mathrm{n}=10$; $U=2.5, \mathrm{p}<0.001$ ). At the end of the experiment areas where crabs were added showed a similar pattern to areas naturally populated by crabs (without crabs: $\bar{x}=$ 1436.6 ind. $\mathrm{m}^{-2}, \mathrm{SD}=571.3, \mathrm{n}=5$; with crabs: $\bar{x}=248.9$ ind. $\mathrm{m}^{-2}, \mathrm{SD}=73.5, \mathrm{n}=5$; $U=0, \mathrm{p}<0.05$; Fig. 3A). Because of the low number of individuals per species, the abundance of meiofaunal organisms was estimated as a pool. Arachnids, larvae and pooled data showed significant differences (Fig. 3A).

\section{Relationship between crabs and characteristics of mature marsh vegetation}

The crab density shows a positive correlation with the percentage of substrata covered by Spartina densiflora $\left(\mathrm{r}^{2}=0.31, \mathrm{n}=63\right.$, $\mathrm{p}<0.001$; Fig. 2A), and no relationship with the stem density of $S$. densiflora $\left(\mathrm{r}^{2}=0.003\right.$, $\mathrm{n}=63, \mathrm{p}>0.05 ; \bar{x}=63.68$ stem m$^{-2}, \mathrm{SD}=5.6$, $\mathrm{n}=63)$. The aboveground dry weight of $S$. densiflora inside the crab populated area
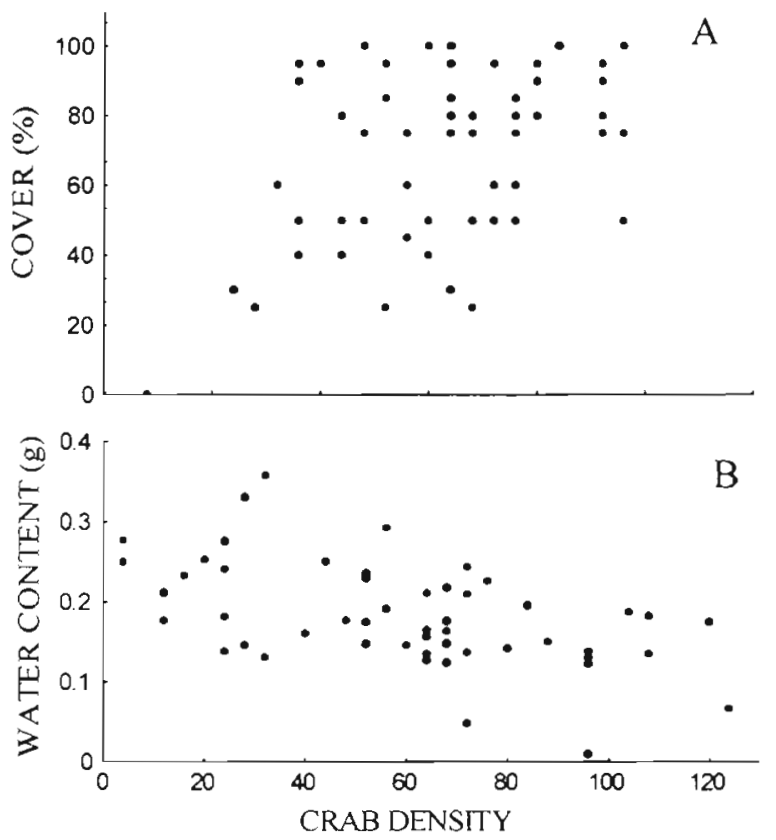

Fig. 2. Relationship between density of Chasmagnathus granulata (ind $\mathrm{m}^{-2}$ ), and (A) percentage of area covered by Spartina densiflora and water content on soil surface (B) expressed as grams of water per sample 
Table 1 Soil characteristics in a cordgrass marsh without crabs (outside) and with crabs (inside). Color classification was based on a Munsell color chart. Within square brackets is the specific color identification reported in the chart

\begin{tabular}{|c|c|c|c|}
\hline Site & Depth & Characteristics & \\
\hline \multirow[t]{2}{*}{ Outside } & 0 to $20 \mathrm{~cm}$ & $\begin{array}{l}\text { Texture: } \\
\text { Color: } \\
\text { Consistence: } \\
\text { Structure: } \\
\text { Organic structures: }\end{array}$ & $\begin{array}{l}\text { clay (> } 40 \%) \\
\text { brown }[10 \mathrm{YR}, 3 / 1] \\
\text { slightly sticky, plastic, or slightly plastic } \\
\text { without. } \\
\text { abundance of small roots (black-brownish layer above } \\
\text { approximately } 5 \mathrm{~cm} \text { depth) and mollusc shells }\end{array}$ \\
\hline & 20 to $40 \mathrm{~cm}$ & $\begin{array}{l}\text { Texture: } \\
\text { Color: } \\
\text { Consistence: } \\
\text { Structure: } \\
\text { Organic structures: }\end{array}$ & $\begin{array}{l}\text { clay }(>40 \%) \\
\text { gray to green }[1.0 Y R, 4 / 1] \\
\text { sticky, plastic } \\
\text { massive } \\
\text { roots and mollusc shells }\end{array}$ \\
\hline Inside & 0 to $40 \mathrm{~cm}$ & $\begin{array}{l}\text { Texture: } \\
\text { Color: } \\
\text { Consistence: } \\
\text { Structure: } \\
\text { Organic structures: }\end{array}$ & $\begin{array}{l}\text { clay (> } 40 \% \text { ) } \\
\text { gray to green [10YR, 4/2] } \\
\text { adhesive, plastic } \\
\text { massive } \\
\text { roots and mollusc shells }\end{array}$ \\
\hline
\end{tabular}

$\left(\bar{x}=1335.84 \mathrm{~g} \mathrm{~m}^{-2}, \mathrm{SD}=458.56, \mathrm{n}=10\right)$ was not significantly different from outside $\left(\bar{x}=1160.32 \mathrm{~g} \mathrm{~m}^{-2}, \mathrm{SD}=\right.$ $\left.272, \mathrm{n}=10, t_{\mathrm{c}}=1.01, \mathrm{df}=18, \mathrm{p}>0.05\right)$. Belowground dry weight inside the crab populated area $(\bar{x}=$ $7728.57 \mathrm{~g} \mathrm{~m}^{-3}, \mathrm{df}=2838.96, \mathrm{n}=5$ ) was also not significantly different from outside $\left(x=7,994.29 \mathrm{~g} \mathrm{~m}^{-3}, \mathrm{SD}=\right.$ $\left.1,917.2, n=5 ; t_{c}=0.17, \mathrm{df}=8, \mathrm{p}>0.05\right)$. The water content of aboveground structures of $S$. densiflora (i.e. wet weight minus dry weight) inside the crab populated area $\left(\bar{x}=834.72 \mathrm{~g} \mathrm{~m}^{-2}, \mathrm{SD}=335.1, \mathrm{n}=10\right)$ was significantly different from outside $\left(\bar{x}=1120.48 \mathrm{~g} \mathrm{~m}^{-2}, \mathrm{SD}=\right.$ $254.2, \mathrm{n}=10 ; t_{\mathrm{c}}=2.15, \mathrm{df}=18, \mathrm{p}<0.05$ ).

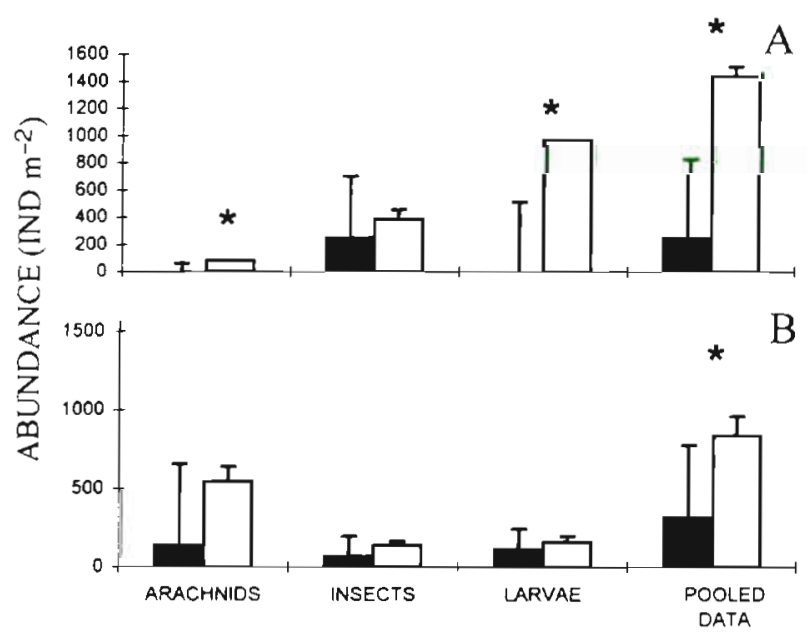

Fig. 3. Soil meiofaunal abundance in (A) natural and experimental (B) Spartina densiflora grassland areas inhabited (black bars) and not inhabited (open bars) by the burrowing crab Chasmagnathus granulata. Values are expressed as $\bar{x}+$

$\mathrm{SD}$. Asterisks indicate significant $t_{\mathrm{c}}$-test values $(\mathrm{p}<0.05)$

\section{Relationship between crabs and characteristics of a recently burned marsh}

The aboveground dry weight of Spartina densiflora inside the crab populated area $\left(\bar{x}=29.39 \mathrm{~g} \mathrm{~m}^{-2}, \mathrm{SD}=\right.$ $11.02, \mathrm{n}=2$ ) was significantly different from outside $\left(\bar{x}=103.06 \mathrm{~g} \mathrm{~m}^{-2}, \mathrm{SD}=17.75, \mathrm{n}=2 ; t_{\mathrm{c}}=4.98, \mathrm{df}=2, \mathrm{p}<\right.$ $0.05)$. This was a conspicuous difference of approximately $87.5 \%$ in aboveground biomass where crabs were present. Belowground dry weight inside the crab populated area $\left(\bar{X}=7646.82 \mathrm{~g} \mathrm{~m}^{-3}, \mathrm{SD}=1,260.44\right.$, $\mathrm{n}=2$ ) was not significantly different than outside $\left(\bar{x}=6057.14 \mathrm{~g} \mathrm{~m}^{-3}, \mathrm{SD}=985.59, \mathrm{n}=2 ; t_{\mathrm{c}}=1.41, \mathrm{df}=2\right.$, $\mathrm{p}>0.05$ )

Young leaves of Spartina densiflora showed no differences in mean growth rate (during a $1 \mathrm{wk}$ span) between areas (paired $t$-test $=1.03, \mathrm{df}=6, \mathrm{p}>0.05$; Fig. 4A), while their survival rate was much lower in the area inhabited by crabs (paired $t$-test $=3.17, \mathrm{df}=6$, $\mathrm{p}<0.05$; Fig. 4B). During the 1 wk experiment, only $55 \%$ of the shoots within the area populated by crabs survived showing a $9 \%(\mathrm{SD}=5.5, \mathrm{n}=7$ ) daily mortality rate of leaves. No losses were observed outside the crab inhabited area.

\section{Experimental evaluation of the effect of crabs on cordgrass and soil structure}

At the end of the first month of experimentation up to $71.5 \%\left(\bar{x}=1681\right.$ leaves $\mathrm{m}^{-2}, \mathrm{SD}=269.6, \mathrm{n}=5 ; t_{\mathrm{c}}=6.2$, $\mathrm{df}=4, p<0.05)$ of the leaves per square meter were dead inside treatment plots (i.e. clipped at approximately $1 \mathrm{~cm}$ from the ground level). Leaves showed no 

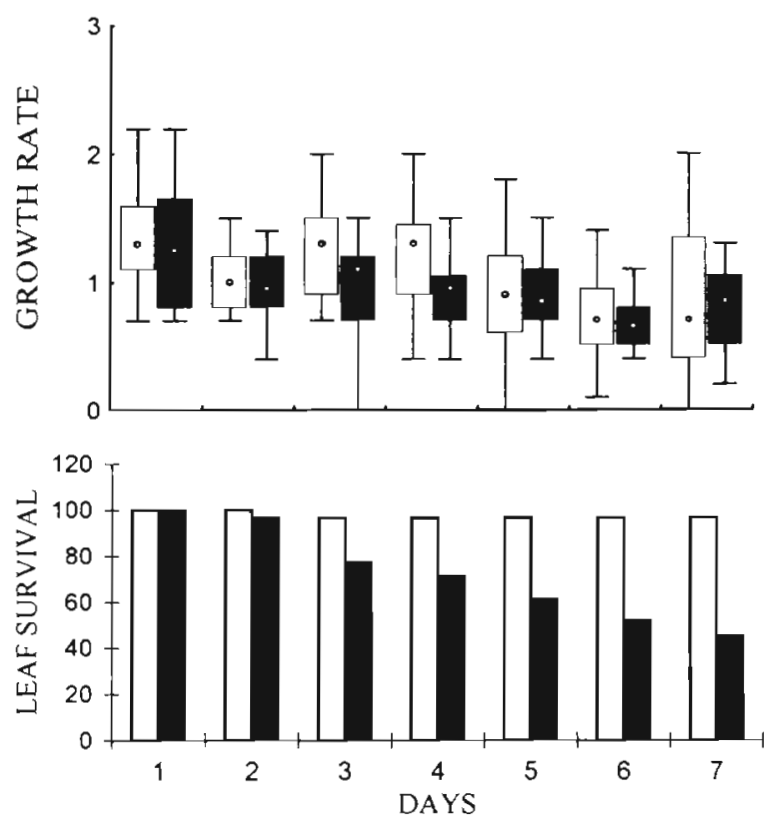

Fig. 4. Growth rate $\left(\mathrm{cm} \mathrm{d}^{-1}\right)$ and leaf survival rate (percentage) of Spartina densiflora in areas inhabited (black boxes and bars) and not inhabited (open boxes and bars) by the burrowing crab Chasmagnathus granulata during a period of $7 \mathrm{~d}$ (March 1996). Box plots are constructed with limits of boxes being the 75th and 25th percentile, lines extending from the boxes represent 10 th and 90 th percentile, dots inside boxes are median values

signs of herbivory in control plots. On 15 October, within the period when crabs showed lower activity, no leaves showed signs of herbivory in either treatment or control plots. During the experiment the activity in all artificial burrows was similar to that in naturally constructed burrows.

Percolation rate was also significantly higher outside the cages $\left(\vec{x}=12.40 \mathrm{ml} \mathrm{min}^{-1}, \mathrm{SD}=8.66, \mathrm{n}=5\right)$ than inside $\left(\bar{x}=3.18 \mathrm{ml} \mathrm{min}^{-1}, \mathrm{SD}=1.97, \mathrm{n}=5 ; t_{\mathrm{c}}=2.3, \mathrm{df}=\right.$ 4.4, $\mathrm{p}<0.05$ ). The soil hardness was significantly higher outside the cages $\left(\bar{x}=119.84 \mathrm{~N} \mathrm{~cm}^{-2}, \mathrm{SD}=3.93\right.$, $\left.\mathrm{n}=5 ; t_{\mathrm{c}}=17.1, \mathrm{df}=8, \mathrm{p}<0.05\right)$ than inside $(\bar{x}=81.18 \mathrm{~N}$ $\mathrm{cm}^{-2}, \mathrm{SD}=3.20, \mathrm{n}=5$ ). On 15 October 1996, each treatment plot showed a homogeneous superficial gray layer $(\bar{X}=95 \%$ of the caged area, $\mathrm{SD}=2.8, \mathrm{n}=5)$, produced by crab remixing of silt sediment, while control plots showed a gray-brownish surface with fissures due to contraction of the sediment. Meiofaunal organisms collected from treatment and control plots were mites (oribatids, prostigmatids, astigmatids, and mesostigmatids), spiders, and a few insects (Collembola, Diptera and Coleopteran). Total abundance of meiofaunal organisms (arachnids + insects + larvae) was higher in control plots $\left(\bar{x}=837.1\right.$ ind. $\mathrm{m}^{-2}, \mathrm{SD}=$ 73.5, $\mathrm{n}=5)$ than in treatment plots $\left(\bar{x}=316.7\right.$ ind. $\mathrm{m}^{-2}$, $\mathrm{SD}=124, \mathrm{n}=5 ; U=1.5, \mathrm{p}<0.05 ;$ Fig. 3B). There were no significant differences, although the data showed a similar trend with the untreated areas (Fig, 3B).

The sediment profiles obtained 20 mo after the start of the crab inclusion experiment showed that crabs generate both discontinuities in the fine root system prevalent in the upper layer and alterations in the upper blackbrownish layer, mainly on the sides of the burrows.

There was no correlation between $\mathrm{pH}$ and depth at any site (treatment plots: $\mathrm{r}^{2}=0.01, \mathrm{n}=15, \mathrm{p}>0.05$; control plots: $r^{2}=0.01, n=15, p>0.05$; Fig. 1). Treatment plots showed no trend in relative water content of the sediment $\left(r^{2}=0.004, n=15, p>0.05\right.$; Fig. 1$)$ and a significant negative correlation of AFDW with depth $\left(\mathrm{r}^{2}=\right.$ $0.7, \mathrm{n}=15, \mathrm{p}<0.05$; Fig. 1). In control plots higher water content was found in surface layers showing a negative trend with depth $\left(r^{2}=0.4, n=15, p<0.05\right)$. The results showed significant differences between treatment and control plots in the relative water content and AFDW of surface layers (Fig. 1).

At the end of the field selection experiment up to $60 \%$ of the young stems were dead inside experimental plots (i.e. clipped at approximately $1 \mathrm{~cm}$ from ground level). There were no signs of herbivory on old stems $\left(t_{c}=4.6, \mathrm{df}=16, \mathrm{p}<0.05\right)$, nor were fragments of leaves found on the soil surface, which could have suggested that leaves of Spartina densiflora may be transported or eaten after being cut.

\section{DISCUSSION}

\section{Relationship between crabs, soil structure and meiofauna}

Accumulation of loose clay and silt on the sediment surface due to burrow maintenance by crabs (burrows are up to $1 \mathrm{~m}$ deep; Iribarne et al. 1997) decreased soil hardness and the superficial percolation rate. The softness of the upper soil and resistance to percolation agree with the inverse relationship between crab density and water content in the surface sediment. Our results also show that accumulation of clay and silt decreases the amount of water taken up by the sediment and may favor the retention of water on the soil surface exposing it to evaporation before percolation. In the study area, crabs can move up to $3 \mathrm{~kg} \mathrm{~m}^{-2} \mathrm{~d}^{-1}$ of sediment (Iribarne et al. 1997). This accumulation of sediment over the soil surface could also reduce the flow of oxygen from the air in to the soil due to increased sediment cohesion (Mendelssohn et al. 1982, Barbour et al. 1987) and waterlogging (Naidoo et al. 1992).

Subsurface drainage is an important factor in determining primary productivity (Chalmers 1982). In contrast to their effect in the upper sediment layer, bur- 
rowing crabs may enhance the overall percolation of water into the soil as a result of their large burrows. These burrows increase soil surface area up to $290 \%$ (Iribarne et al. 1997), a value much higher than the $22 \%$ in a salt marsh in Georgia (Teal \& Kanwisher 1961) and 59\% in Massachusetts (Katz 1980). This increase in surface area can aid growth by directly removing toxins from the root zone (Howes et al. 1981, Chalmers 1982), or facilitating the circulation of oxygen available to plants. However, the alteration of drainage and pounding-up of water may result in the death of some plant species, or in a high production of new roots with a higher proportion of aerenchyma (Adam 1993). Interestingly, in the area with crabs the upper layer of small roots was not present and the water content was significantly lower. Our experimental results showed that crabs lead to the disappearance of small roots from the upper soil layer and a decrease in the amount of water retained in the sediment. This pattern suggests that the small roots increase the retention of water. The brownish color and the values of AFDW (organic matter) in the upper layer in areas without crabs indicate a higher content of organic matter when compared with the other layers, and even more so than at the same soil depth in the area with crabs. The results from the experiment showed a similar pattern in the distribution of AFDW in the sediment. The fact that in the crab populated areas, AFDW was dispersed homogeneously in the sedimentary column may be due to remixing generated by crabs (Takeda \& Kurihara 1987). At the border between areas populated and non-populated by crabs where soil horizons begin to appear, the activity of crabs could return silt and clay sediments to the surface, recovering the material eluviated from the upper strata together with associated organic nutrients.

The concordance between field patterns and experimental results suggests that crabs generate a decrease in the abundance of soil meiofauna (mainly detritivorous: Seastedt 1984), and also in the layer of small roots. This effect on meiofauna may be due to a decrease in the availability of shelters and food due to the absence of the layer of small roots (Seastedt 1984), or the accumulation of clay and silt sediments on the surface, which would decrease the availability of free oxygen (Mendelssohn et al. 1982). Our results also suggest that burrowing crabs bury surface plant debris and its associated meiofauna in places where they inhabit. The disturbances generated by Chasmagnathus granulata may also retard the process of recolonization by meiofauna due to lower availability of resources. All these changes in surface soil shape, hardness, and percolation rate generated by crabs after experimentation were similar to those described in natural areas populated by crabs, which exemplifies their ability to alter the environment in a relatively short time.

\section{Relationship between crabs and characteristics of a mature marsh vegetation}

Numerous works have demonstrated that the salt marsh's most common herbivores are insects, arachnids, and a few crustaceans (e.g. Crawley 1983, Adam 1993, Mitsch \& Gosselink 1993), but direct herbivory is very low (up to $4.6 \%$ of net aboveground production; Teal 1962). The crab Sesarma reticulatum has been recorded as being capable of reducing tall creekbank stands of the cordgrass Spartina alterniflora to stubble. However, the same pattern was not seen at other similar sites where the crab also occurs (Pfeiffer \& Weigert 1981 cited by Adam 1993). The relatively low consumption of salt marsh plants by grazers may be related to the low nutritive quality of these plants and the relatively high concentration of secondary plant substances (Valiela 1984)

Mature Spartina densiflora did not show variation in aboveground or belowground dry biomass, in relation to crab presence. Neither were there variations in stem density in relation to crab density. Nevertheless, the cover of $S$. densiflora showed a positive correlation with crab density. With an equal stem density and equal aboveground biomass with and without crabs, higher $S$. densiflora cover must be due to changes in the erection of stems and leaves produced by changes in water content. Plants can adjust the size and distribution of shoot canopies in response to changes in the external supply of resources (Campbell et al. 1991). This pattern suggests that the soil drainage and waterlogging variability generated by crab activity affects the architecture of $S$. densiflora by altering the availability of resources (Howes et al. 1981). The presence of a layer of small roots of $S$. densiflora in the area without crabs is evidence of changes in belowground plant morphology. Although the difference in AFDW of the sediment surface between areas with and without crabs was due to this layer of roots, the difficulties in extracting them from the soil make it impossible to precisely evaluate their weight.

\section{Relationship between crabs and characteristics of a recently burned marsh}

Our previous study (Iribarne et al. 1997) based on stomach content analysis suggested that the burrowing crab Chasmagnathus granulata is mainly herbivorous in Spartina-dominated grasslands, while it is a deposit feeder when living in mudflats. Here we show 
that this crab feeds on new shoots of $S$. densiflora causing a decrease of $87.5 \%$ of their aboveground biomass. The observed effect on the shoots of $S$. densiflora after a brush fire was probably due to their relatively higher palatability, compared with older leaves which are silica fortified and less digestible (Howe \& Westley 1988). This conclusion agrees with the selection of young totally green stems by crabs during the field experiment. However, in mature $S$. densiflora grasslands new shoots are less numerous and are protected by older leaves, thus the impact of direct herbivory is low (although herbivory could occur). Under such conditions it is likely that burrowing crabs feed on detritus of $S$. densiflora, which may be more digestible during the process of decomposition (Halupa \& Howes 1995). However, it is interesting that the primary production in this salt marsh can vary as a function of the availability of new shoots.

The effect of burrowing crabs on Spartina densiflora can be variable in both the modus and magnitude of the physical changes produced in the environment and of leaves eaten. The state of the stems (i.e. mature vs young) could also affect crabs by generating different trophic behaviors, from detritivory to herbivory. It is well known that the slow accumulation of detritus through decomposition is one of the most important sources of nutrients in estuarine environments (Valiela 1984, Mitsch \& Gosselink 1993). Crabs can affect plant debris and new shoots when both are available, but only plant debris in mature marsh areas where new shoots are less available. Thus, burrowing crabs may use primary production in the marsh environment, adopting different strategies depending on the plant stage (i.e. mature vs regrowing), probably optimizing the intake of nutrients from the vegetal fraction.

As a general conclusion, our results show that crabs can have a strong effect on the marsh soil structure and its quality, principally by remixing of sediment, which in turn affects the architecture of mature Spartina densiflora. Crabs also eat the new shoots of $S$. densiflora, which has an important impact on the production of aboveground structures during rejuvenation periods. However, to make global conclusions and inferences (i.e. beyond SW Atlantic salt marshes), large scale experiments are needed (Hulbert 1984). The trophic flexibility of the burrowing crab (Iribarne et al. 1997), combined with its high endemism, may allow it to have a strong localized effect on salt marsh production. This effect could vary through time depending on the frequency of factors such as brush fires or vegetation cutting that enhance the availability of new shoots. Considering this, Teal's (1962) conclusion that in Spartina marshes only a small proportion of primary production is consumed in situ may not apply to the SW Atlantic Spartina marshes inhabited by crabs.
Acknowledgements. This project was supported by the Universidad Nacional de Mar del Plata, CONICET and the International Foundation for Sciences (No. A/2501-1). One of us (A.B.) was supported by a ClC (Buenos Aires, Argentina) scholarship. This work is part of the doctoral thesis of A.B. at the UNMDP. We thank A. Vasallo for lending us the penetrometer, P. Martinez for identifying meiofaunal organisms, and $M$. Tonello for field assistance. We also thank P. Laterra, E. Schwindt, and 4 anonymous referees for very useful comments and corrections on the manuscript. This paper is dedicated to the memory of Professor Mariano Manuel Martinez. He was an excellent teacher, an outstanding scientist, and an even better friend.

\section{LITERATURE CITED}

Adam P (1993) Saltmarsh ecology. Cambridge studies in ecology. Cambridge University Press, Cambridge

Barbour GM, Burk JH, Pitts WD (1987) Terrestrial plant ecology. The Benjamin/Cummings Publishing Company, Inc, Menlo Park. CA

Bertness MD (1985) Fiddler crab regulation of Spartina alterniflora production on a New England salt marsh. Ecology 66:1042-1055

Bond WJ, van Wilgen BW (1996) Fire and plants. Chapman and Hall, London

Boschi EE (1964) Los Crustáceos Decápodos Brachyura del litoral Bonaerense. Bol Inst Biol Mar Mar Del Plata 6:1-99

Brown AC, Mc Lachlan A (1990) Ecology of sandy shores. Elsevier Science Publishers BV, New York

Cabrera (1978) Manual de la flora de los alrededores de Buenos Aires. Editorial Buenos Aires, Buenos Aires

Campbell BD, Grime JP, Mackey JML (1991) A trade-off between scale and precision in resource foraging. Oecologia 87:532-538

Chalmers AG (1982) Soil dynamics and the productivity of Spartina alterniflora. In: Kennedy US (ed.) Estuarine comparisons. Academic Press, New York, p 231-242

Crawley MJ (1983) Herbivory: the dynamics of animal-plant interactions. University of California Press, Berkeley

Day JW Jr, Hall CAS, Kemp WM, Yañez-Arancibia A (1989) Estuarine ecology. Wiley-Interscience Publication, New York

Fasano J, Hernández M, Isla F, Schnack E (1982) Aspectos evolutivos y ambientales de la laguna Mar Chiquita (provincia de Buenos Aires, Argentina). Oceanol Acta No. spec.:285-292

Halupa PJ, Howes BL (1995) Effects of tidally mediated litter moisture content on decomposition of Spartina alteniflora and S. patens. Mar Biol 123:379-391

Howe HF, Westley LC (1988) Ecological relationships of plants and animals. Oxford University Press, New York

Howes BL, Howarth RW, Teal J, Valiela I (1981) Oxidationreduction potentials in a salt marsh: spatial patterns and interactions with primary production. Limnol Oceanogr 26:350-360

Hulbert S (1984) Pseudoreplication and the design of ecological field experiments. Ecol Monogr 54:187-211

Iribarne O, Bortolus A, Botto F (1997) Between-habitat differences in burrow characteristics and trophic modes in the southwestern Atlantic burrowing crab Chasmagnathus granulata. Mar Ecol Prog Ser 155:137-145

Katz LC (1980) Effects of burrowing by the fiddler crab, Uca pugnax (Smith). Estuar Coast Mar Sci 2:233-237

Mendelssohn IA, McKee KL, Postek MT (1982) Sublethal stresses controlling Spartina alterniflora productivity. In: Gopal B, Turner RE, Wetzel RC, Whigham DF (eds) Wet- 
lands ecology and management. National Institute of Ecology and International Scientific Publications, Jaipur, p 223-242

Mitsch WJ, Gosselink JG (1993) Wetlands. Van Nostrand Reinhold, New York

Munsell Color Company (1975) Munsell soil color chart. Munsell Color Company Inc, Baltimore, MD

Naidoo G, McKee KL, Mendelssohn IA (1992) Anatomical and metabolical responses to waterlogging and salinity in Spartina alterniflora and S. patens (Poacea). Am J Bot 79: $765-770$

Olivier SR, Escofet AM, Penchaszadeh P, Orensanz JM (1972) Estudios ecológicos de la región estuarial de Mar Chiquita (Buenos Aires, Argentina). 1. Las comunidades bentónicas. An Soc Cient Argent 193:237-262

Pfeiffer WJ, Weigert RG (1981) Grazers on Spartina and their predators. In: Pomeroy LR, Weigert RG (eds) The ecology of salt marsh. New York (cited after Adam 1993)

Rhodes D (1967) Biogenic reworking of intertidal and subtidal sediments in Barnstable Harbor and Buzzards Bay, Mass. J Geol 75:461-474

Santos EA, Baldisseroto B, Bianchini A, Colares EP, Nery LEM, Manzoni GC (1987) Respiratory mechanisms and metabolic adaptation of an intertidal crab, Chasmagnathus granulatus (Dana, 1851). Comp Biochem Physiol 88A:21-25

Editorial responsibility: Otto Kinne (Editor),

Oldendorf/Luhe, Germany
Seastedt TR (1984) The role of microarthropods in decomposition and mineralization processes. Annu Rev Entomol 29 $25-46$

Southwood TRE (1975) Ecological methods. Chapman and Hall, London

Spivak E, Anger K, Luppi T, Bas C, Ismael D (1994) Distribution and habitat preferences of two grapsid crab species in Mar Chiquita Lagoon (Province of Buenos Aires, Argentina). Helgol Meeresunters 48:59-78

Strahler AN, Strahler AH (1994) Geografía fisica. Omega, SA, Barcelona

Takeda S, Kurihara Y (1987) The effects of burrowing of Helice tridens (De Haan) on the soil of a salt-marsh habitat. J Exp Mar Biol Ecol 113:76-89

Teal JM (1962) Energy flow in the salt marsh ecosystem of Georgia. Ecology 43:614-624

Teal JM, Kanwisher JW (1961) Gas exchange in a Georgia salt marsh. Limnol Oceanogr 6:388-399

Valiela I (1984) Marine ecological processes. Springer-Verlag. New York

Wolcott DL, O'Connor NJ (1992) Herbivory in crabs: adaptations and ecological considerations. Am Zool 32 $370-381$

Zar JH (1984) Biostatistical analysis. Prentice-Hall, Inc, Englewood Cliffs, NJ

Submitted: Apri1 24, 1998; Accepted: October 20, 1998

Proofs received from author(s): March 8, 1999 